\section{P-357後腹膜腔鏡下副腎部分切除術の副腎皮質機 能について}

\section{山形大学 医学部 泌尿器科1)}

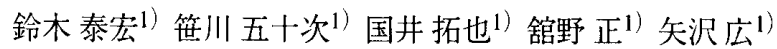
庄司則文1) 久保田 洋子.1）中田瑛浩1)

【目的】副腎部分切除術の意義を明らかにするため、副腎部分 切除群と副腎全摘除群の副腎皮質機能を比較した。【対象と方法】 1996年4月から 1999年9の間に後腹膜腔鏡下副腎摘除術を施行した 非機能性副腎腫湯22例を、全摘群12例、部分切除群10例に分けた。 而群の術前後の迅速ACTH試験、CRH試験、ACTHおよびコーチゾ 一ルの日内変動を比較した。結果】迅速ACTH試験では両群とも 術後コーチゾールの反応が術前より低下したが、部分切除群の方 が反応が良好だった。CRH試験では両群とも術前後のACTHの反 応には差が無かったが、術後のコーチゾールの反応は部分切除群 の方が良好だった。日内変動では、コーチゾールは両群とも術前 後で差は無かったが、ACTHは術後に午前の值が上昇しており、 これは全摘群で顕著だった。【考案】副腎腫瘍に対する後腹膜腔 鏡下副腎部分切除術は、副腎皮質機能温存のため有用と考えられ た。

\section{副腎部分切除術 副腎皮質}

\section{P-358 後腹膜腫癘手術症例の臨床的検討}

\section{大阪大学 大学院 医学系研究科 䑏器制御外科学講座} 泌尿器科学1)

垣本 健一 1) 辻畑 正雄1）吉村一宏1) 三宅修1) 野々村祝夫1） 松宮 清美1）小角 幸人1）高原 史郎1）奥山明彦1）

【目的】後腹膜腫瘍は、過半数が悪性腫瘍であるとされ治療に難 渋することも多い。当科で最近10年間に経験した後腹膜腫瘍手術 症例について検討した。【対象と方法】1989年以降に当科で手術を 行い得た後腹膜腫瘍のうち、副腎腫場と診断されたものを除外し た28例（24人）を対象とした。年齢は4～72歳（平均48歳）、男性 11例、女性17例であった。以上の症例を retrospectiveに検討した。 【結果】発見の契機は腹部膨隆、疼痛がほとんどで、無症状で発 見されたものは再発例を除き3例であった。摘出腫瘍平均重量は 890 グラムで最大は10キログラムであった。病理組織は、血管筋脂 肪腫2例、神経鞘腫2例、平滑筋腫1例、神経節腫1例、リンパ管腫1 例、異所性褐色細胞腫 1 例、脂肪肉腫 9 例、平滑筋肉腫 4 例、悪性 神経鞘腫 2 例、悪性線維性組織球腫 1 例、横紋筋肉腫 1 例、覀性リ ンパ腫1例、悪性間葉腫1例であった。悪性後腹膜腫瘍20例中11例 は腫瘍摘除術に加之周囲臟器の合併切除を要した。さらに外科的 治療に加之術前または術後に抗癌剤治療を行ったもの、放射線療 法を行ったものはそれぞれ3例、2例であったが、予後不良であっ た。【結論】悪性後腹膜腫演でも完全摘除できれば比較的予後良 好であると考えられた。

後腹膜腫㾣 臨床的検討

\section{P-359 慢性血精液症に対する経尿道的内視鏡手術}

古屋病院 ${ }^{1)}$

古屋 聖兒1) 小椋 啓1) 島村 昭吾1)

血精液症は一般に自然治瘾の傾向が強い疾患であるが，まれに1 年から数年にわたり，持続的，反復的に症状を示す慢性血精液症 が存在する. 今回我々は，経尿道的内視鏡手術により，劇的に血 精液症が消失した慢性血精液症の3症例を報告する. [症例1]48歳, 2 年以上持続する血精液症. [症例2]59歳, 1 年以上持続する血精液 症. [症例3]36歳, 6 年間にわたり, 年1〜2回繰り返す血精液症. 原因疾患の診断のため, 経直腸的超音波検査(TRUS), TRUS監視 下経会陰的精豪腺掞よび骨盤内正中線囊胞針穿刺，精管精衰腺造 影を行なった，その結果, 症例1と2は左射精管と交通しているミ ュラー管衰胞, 症例 $3 は$ 右射精管閉塞と診断した。治療は, 症例1 と2は経尿道的ミュラー管衰胞開空術, 症例 3 は経尿道的射精管切 開術を行なった，方法は，症例1と2では，豪胞にインジゴカルミ ン色素を注入後, 症例 3 は, 精管より色素を注入後, 精丘と膀胱 頸部の間の尿道を少しづつ切開し，色素の噴出を確認するまで切 開した.この場合，切開の部位と深さを決めるのにTRUSは極め て有用であった，手術による合併症は認められなかった．全例術 後血精液症は消失し, 現在まで, 症例 1 は2年4ヶ月, 症例 2 は 2 ケ, 症例 3 は 1 年 8 ケ月血精液症の再発は認めていない.

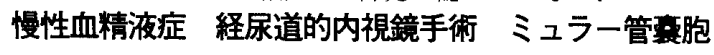

\section{P-360 摘出ラット陰茎海綿体平滑筋の驰緩反応に 及ぼす除睪術の影響}

\begin{abstract}
熊本大学 医学部 泌尿器科1)
桑原朋広 1 和田 孝浩1）高橋渡 ${ }^{1}$ 吉田 正貴 1 ）菊川浩明1） 岩下仁 ${ }^{1)}$ 上田昭一

海綿体平滑筋の驰緩にはnitric oxide(NO)がneurotransmitterとして働い ていると考えられている。また、testosteroneは海綿体平滑筋機能を 含む性機能に対して様々な影響を及ぼすと考えられている。今回 我々は雄性ラット海綿体平滑筋のNOを介した弛緩反応に対する除 睪術の効果を検討した。【方法】8週齢雄性ラットに対し両側除 睪術を施行し、偽手術を施行したものをcontrolとして比較した。 除睪術 2 ケ後、penisの重量を両群で比較した。また、海綿体平 滑筋条片をorgan bath内に懸垂固定し、phenylephrine前収縮下におけ る経壁電気刺激による弛緩反応と microdialysis法による経壁電気刺 激時のNO放出量を両群で比較検討した。さらに、sodium nitroprussideによる弛䋸反応も両群で比較検討した。【結果】除睪術 群ではpenisの重量はcontrol群に比し有意に小さかった。除辠術群 ではcontrol群に比し有意に驰緩反応およびNO放出量はが充進され た。 sodium nitroprussideによる弛緩反応には両群に有意差は見られ なかった。【結論】testosteroneは雄性ラット海綿体平滑筋において NOを介した弛緩反応を抑制している可能性が示唆された。
\end{abstract}

隍蕉海綿体 Nitric Oxide Testosterone 